\title{
Kearifan Lokal Padi Ratun Sebagai Upaya Mitigasi dan Adaptasi Perubahan Iklim Di Desa Wonosari Kecamatan Gondangrejo
}

\author{
Komariah*1, Ariyanto D. P. $^{1}$, Sumani ${ }^{1}$, Yanti Y. ${ }^{2}$, Setyawati A. ${ }^{3}$, Priswita R. P.W. ${ }^{4}$ \\ ${ }^{1}$ Program Studi Ilmu Tanah; Fakultas Pertanian, Universitas Sebelas Maret, Surakarta \\ ${ }^{2}$ Program Studi Peternakan, Fakultas Pertanian, Universitas Sebelas Maret, Surakarta \\ ${ }^{3}$ Program Studi Agroteknologi, Fakultas Pertanian, Universitas Sebelas Maret, Surakarta \\ ${ }^{4}$ Program Studi Ilmu Lingkungan, Fakultas Pasca Sarjana, Universitas Sebelas Maret \\ *email : komariah23@gmail.com
}

\begin{abstract}
Abstrak
Berbagai inovasi untuk meningkatkan produktivitas padi dan pencapaian target produksi telah dihasilkan Badan Penelitian dan Pengembangan Pertanian (Balitbangtan). Saat ini salah satu teknologi budidaya padi yang berpotensi untuk dikembangkan adalah budidaya padi ratun. Di Sumatera Barat teknologi padi ratun yang banyak dipraktikkan adalah budidaya padi salibu. Budidaya padi salibu merupakan teknologi budidaya yang telah dimodifikasi disesuaikan dengan daerah Sumatera. Budidaya padi ratun memiliki beberapa keuntungan seperti lebih hemat tenaga, biaya dan benih, tanpa pengolahan tanah, tanam sekali panen dua-tiga kali. Penelitian ini dilakukan dengan melakukan penyuluhan, FGD dan pendampingan di Desa Wonosari Gondangrejo, Karanganyar. Hasil penelitian menunjukkan budidaya padi ratun dapat dimanfaatkan untuk mengantisipasi dampak perubahan iklim seperti ketersediaan air yang makin terbatas jika 3 faktor seperti modifikasi teknologi budidaya padi ratun secara jelas, mengoptimalkan kinerja penyuluh pertanian dan kelompok tani, pembentukan kawasan budidaya padi ratun.
\end{abstract}

Kata kunci-Salibu, modifikasi teknologi, pengabdian, masyarakat

\section{Pendahuluan}

Saat ini bumi sedang mengalami perubahan iklim yang harus dihadapi, tidak terkecuali sektor pertanian. Sektor pertanian menjadi sektor yang sangat rentan terhadap perubahan iklim. Perubahan iklim dapat menyebabkan kekeringan, banjir dan pola curah hujan yang berubah yang dapat menurunkan hasil panen. Maka diperlukan salah satu tindakan untuk melakukan adaptasi dan mitigasi untuk menghadapi perubahan iklim agar dapat mengurangi dampak negatif dari perubahan iklim. Salah satu tindakan yang dapat dilakukan adalah kearifan lokal dari masyarakat itu sendiri.

Di bidang pertanian, kearifan lokal menjadi salah satu langkah petani dalam melakukan upaya adaptasi dan mitigasi terhadap perubahan iklim, karena kearifan lokal merupakan tradisi dari nenek moyang yang ada dan dimiliki oleh masyarakat tersebut. Maka kearifan lokal dapat digunakan untuk mengatasi masalah pertanian ada sekarang ini dengan kembali menggunakan teknologi dari kearifan lokal. Salah satu kearifan lokal yang berpotensi untuk dikembangkan dalam menghadapi perubahan iklim adalah kearifan lokal budidaya padi ratun.

Padi ratun (ratoon) adalah tanaman padi yang berasal dari tunas yang tumbuh dari tunggul yang telah dipanen dan menghasilkan anakan baru hingga dapat dipanen. Budidaya padi secara ratun belum banyak diterapkan oleh petani karena umumnya padi ratun memiliki daya hasil yang lebih rendah dibanding tanaman pertama. Daya hasil yang tinggi sebenarnya dapat diperoleh jika manajemen budidaya ratun dilakukan dengan baik (Nainggolan et al., 2013).

Saat ini, sistem ratun lebih populer digunakan pada budidaya tebu dibandingkan padi. Keuntungan penerapan teknologi ratun adalah cepat, mudah dan murah serta dapat meningkatkan produktivitas padi per unit area dan per unit waktu (Nair \& Rosamma 2002). Budidaya padi ratun adalah teknologi dengan memotong batang padi kemudian rumpun padi menghasilkan anakan baru setelah rumpun tanaman pertama dipanen. Padi ratun 
dengan sistem salibu telah dikembangkan di daerah Sumatera Barat dan menghasilkan produksi yang lebih tinggi dibandingkan dengan sistem konvensional yang digunakan oleh petani.

Pengabdian ini dilaksanakan di Desa Wonosari Gondangrejo yang memiliki persawahan dengan sistem lahan tadah hujan. Sesuai dengan kondisi alam Desa Wonosari yang berbentuk pegunungan, maka sebagian besar penduduknya mempunyai mata pencaharian di sektor petani baik sebagai petani maupun buruh tani (BPS, 2019). Hingga saat ini pemanfaatan lahan tadah hujan di Desa Wonosari masih belum dimanfaatkan dengan optimal. Dengan diadakannya kegiatan pengabdian masyarakat pengembangaan budidaya padi ratun diharapkan dapat meningkatkan pemanfaatan lahan sehingga pendapatan masyarakat meningkat. Peningkatan pendapatan masyarakat diharapkan dapat meningkatkan kesejahteraan masyarakat Wonosari.

\section{Metode Pelaksanaan}

Pengabdian kepada masyarakat (PKM) mengenai Pengembangan Kearifan Lokal Padi Ratun Sebagai Upaya Mitigasi Dan Adaptasi Perubahan Iklim ini akan dilakukan dengan metode sebagai berikut:

1. Waktu dan Tempat

Pengabdian ini dilaksanakan sejak Bulan April sampai dengan Oktober 2020, di Desa Wonosari, Kecamatan Gondangrejo, Kabupaten Karanganyar, Jawa Tengah. Penelitian ini dilaksanakan dengan menggunakan metode deskriptif kualitatif. Teknik pengumpulan data diperoleh melalui observasi, wawancara dan dokumentasi.

2. Metode Transfer Teknologi Padi Ratun

Metode transfer teknologi dilakukan dengan 2 teknik, yaitu:

a. Penyuluhan.

Penyuluhan pertanian merupakan upaya untuk mempengaruhi pola pikir dan mengubah perilaku petani dan keluarganya, agar mengetahui manfaat dari budidaya padi ratun, serta tertarik untuk menerapkannya.

b. Pembuatan Demplot.

Demplot atau Demontration Plot merupakan suatu metode penyuluhan pertanian kepada petani dengan membuat lahan percontohan, agar petani bisa melihat dan membuktikan apa yang menjadi target dari objek yang didemonstrasikan. Maka dalam kegiatan ini akan dibuat demplot sistem penanaman padi ratun seluas 1 hektar, untuk memberikan bukti kepada petani bahwa sistem penanaman padi ratun cukup menjanjikan menjaga produktivitas, namu sangat hemat air.

3. Pendokumentasian

Pendokumentasian kegiatan pengabdian ini dilakukan dengan 2 metode, yaitu pendokumentasian dalam bentuk video dan publikasi.

\section{Hasil Dan Pembahasan}

Desa Wonosari terletak di Kecamatan Gondangrejo Kabupaten Karanganyar Provinsi Jawa Tengah. Wonosari memiliki ketinggian tempat $117 \mathrm{mdpl}$. Sesuai dengan kondisi alam Desa Wonosari yang berbentuk pegunungan, maka sebagian besar penduduknya mempunyai mata pencaharian di sektor petani baik sebagai petani maupun buruh tani. Tanaman yang sering ditanam di Desa Wonosari adalah padi, jagung, kacang tanah dan ketela pohon. Selain menjadi petani, masyarakat juga memiliki ternak. Hewan yang biasa dipelihara yaitu sapi potong, kambing, babi, ayam ras dan ayam buras (BPS, 2019). Di desa Wonosari terdapat 6 kelompok tani yang terdapat di setiap dusun. Mitra dalam kegiatan pengabdian masyrakat ini adalah kelompok tani Makmur 1 (Gambar 1). Selain itu, kelompok tani Makmur 1 merupakan kelompok tani yang aktif dalam melakukan kegiatan. Lahan sawah di Desa Wonosari, Gondangrejo termasuk ke dalam lahan tadah hujan. Petani hanya bisa melakukan 2 kali musim tanam dengan komoditas padi dan jagung atau kacang tanah atau singkong. Karena keadaan tersebut maka lahan tadah hujan dirasa sangat cocok untuk budidaya padi ratun. Petani Wonosari tertarik untuk melakukan praktik budidaya padi ratun (Gambar 2). Dengan menghidupkan kembali kearifan lokal budidaya padi ratun maka diharapkan sikap adaptasi dan mitigasi perubahan iklim masyarakat Wonosari dapat meningkat. 

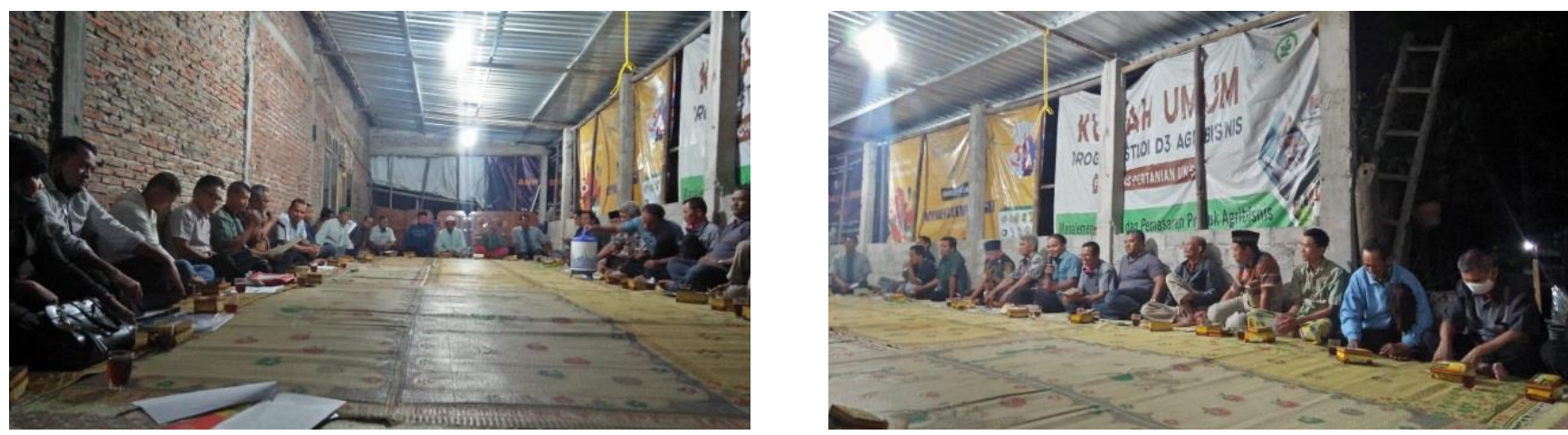

Gambar 1. Kelompok tani Makmur 1, Desa Wonosari, Kecamatan Gondangrejo Kabupaten Karanganyar Provinsi Jawa Tengah

Padi ratun merupakan kearifan lokal yang ada di beberapa daerah di Indonesia. Kearifan lokal padi ratun telah ada dan tidak dibudidayakan secara intensif, petani hanya memanfaatkannya. Di beberapa daerah saat ini petani hanya memanfaatkan padi ratun namun tidak membudidayakan dengan sengaja. Padi yang telah dipanen dibiarkan tumbuh kembali untuk dimanfaatkan sebagai pakan ternak. Saat ini pada umumnya padi ratun (singgang) hanya dianggap sebagai tanaman bonus oleh petani apa yang dihasilkan dipanen tanpa ada perawatan, pemumpukan, penyiangan sehingga tidak banyak yang diharapkan dari hasil padi ratun. Padi singgang yang dibiarkan tumbuh tanpa dirawat dengan intensif memiliki hasil panen yang cukup rendah dibandingkan tanaman utamannya. Selain di Pulau Jawa, terdapat pula kearifan lokal di Sumatera Barat yang memanfaatkan anakan padi yang tumbuh setelah panen yang disebut salibu. Pada jaman dahulu salibu dimanfaatkan oleh orang yang tidak mampu/tidak mempunyai modal untuk musim tanam kedua sehingga membudidayakan kembali anakan padi yang tumbuh setelah dipotong pendek. Namun pada saat ini salibu telah memiliki sentuhan inovasi teknologi sehingga keberhasilan salibu lebih tinggi dibandingkan singgang. Selain itu, di Kalimantan Selatan juga ada budidaya padi ratun yang memanfaatkan lahan pasang surut. Selain di Indonesia, padi ratun juga telah banyak dipraktikkan di berbagai negara seperti Cina, Jepang, Laos, Myanmar, dan Thailand. Namun budidaya padi ratun di luar negeri sudah ada pendekatan teknologi sehingga dapat meminimalkan kekurangan menurunnya hasil panen.
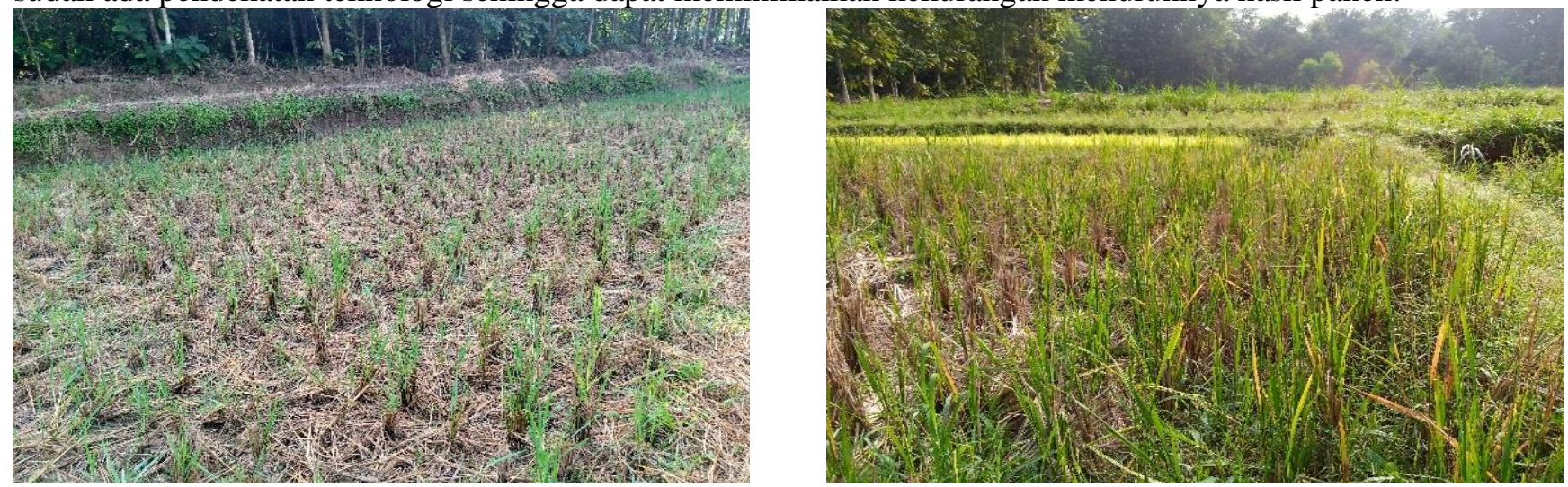

Gambar 2. Petani tertarik untuk melakukan praktik budidaya padi ratun di desa Wonosari, Kecamatan Gondangrejo Kabupaten Karanganyar Provinsi Jawa Tengah

Meskipun produktivitas menurun setelah masa tumbuh kedua, dengan teknologi budidaya yang lebih baik, produktivitas padi dapat ditingkatkan. Sehingga juga dapat menambah pendapatan petani. Bahkan teknologi budidaya ratun ini sudah dikembangkan di provinsi Jawa Timur, dimana produktivitas dapat ditingkatkan menjadi dua kali lipat tanpa melakukan penanaman ulang (Voa Indonesia, 2019). Selain meningkatkan produksi pertanian, keuntungan lain dari sistem ratun ini yaitu hemat dalam pemenuhan faktor produksi, hemat biaya dan tenaga kerja, serta mengurangi waktu persiapan lahan.

Untuk membuat sebuah kawasan maka diperlukan keadaan yang saling mendukung dari berbagai aspek seperti teknis, sosial, ekonomi dan budaya yang perlu diperhatikan secara menyeluruh. Jika budidaya pertanaman telah dipraktikkan secara intensif maka aspek teknis seperti hama dan penyakit di kawasan tersebut harus sangat diperhatikan. Jika lahan tersebut merupakan lahan irigasi maka yang perlu diperhatikan adalah ketersediaan air. 
Jika hanya ada satu atau dua petani yang mempraktikkan budidaya ratun maka tidak akan terjadi sinkronisasi di kawasan tersebut. Petani lain yang tidak mempraktikkan ratun pada saat masa panen air tidak mengalir namun pada saat itu untuk budidaya padi ratun membutuhkan air untuk menumbuhkan kembali anakannya. Meskipun sudah ada pendektan teknologi, namun aspek sosial dan budaya juga harus diperhatikan. Begitu pula saat musim panen, budidaya padi ratun memiliki waktu panen yang lebih dulu dibandingkan budidaya umumnya. Jika kawasan tersebut merupakan kawasan endemik burung atau tikus maka budidaya padi ratun akan menjadi sasaran untuk hama tersebut. Oleh karena itu jika ingin mengembangkan kawasan padi ratun maka diperlukan keadaan yang saling mendukung seperti air yang mengalir sepanjang tahun.

Budidaya padi ratun memiliki potensi yang besar khususnya untuk lahan tadah hujan. Namun untuk memperoleh manfaat atau keuntungan budidaya padi ratun ada beberapa syarat yang harus dipenuhi. Syarat tersebut antara lain :

1. Pendekatan teknologi yang jelas (harus sudah jelas pengaplikasiannya) untuk panduan budidaya padi ratun yang tepat agar hasil panen budidaya padi ratun lebih optimal. Pendekatan sosial dan budaya yang sesuai untuk kawasan budidaya padi ratun.

2. Pembuatan wilayah khusus untuk kawasan budidaya padi ratun. Khusus untuk budidaya padi ratun harus sudah jelas klasifikasi wilayah (kriteria wilayah) untuk pengembangan harus jelas karena budidaya padi ratun tidak bisa dipraktikkan pada semua jenis lokasi yang umum.

3. Diseminasi teknologi. Pendekatan teknologi harus dikuasai oleh diseminator (yaitu penyuluh) dan harus ada kebun percontohan.
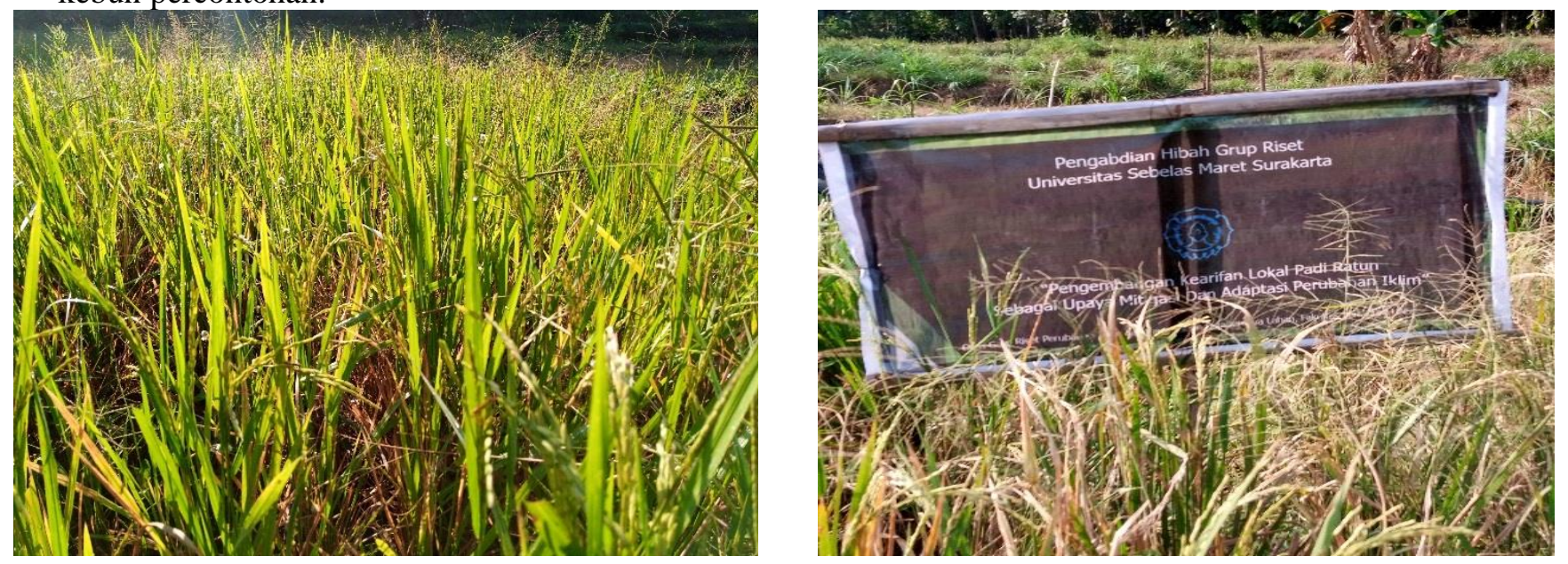

Gambar 3. Pengembangan Padi Ratun d Desa Wonosari, Kecamatan Gondangrejo Kabupaten Karanganyar Provinsi Jawa Tengah

Untuk mengembangkan segala macam teknologi termasuk pengembangan padi ratun maka diperlukan desimenator yaitu orang yang menyalurkan atau menyampaikan teknologi tersebut (Gambar 3). Universitas Sebelas Maret (UNS) yang merupakan perguruan tinggi dan lembaga riset memiliki peran penting dalam pengembangan teknoogi dan menyalurkan kemasyarakat. Budidaya padi ratun dianggap lebih efisien namun jika digunakan untuk adaptasi dan mitigasi perubahan iklim secara global mungkin masih kurang karena konteksnya yang terlalu jauh. Budidaya padi ratun dapat digunakan sebagai tindakan mitigasi pada ruang lingkup yang lebih kecil. Budidaya padi ratun dapat dimanfaatkan untuk mengantisipasi dampak perubahan iklim seperti ketersediaan air yang makin terbatas jika 3 faktor di atas terpenuhi.

Penerapan teknologi ratun salibu lebih efisien karena dapat menghemat penggunaan benih, air dan tenaga kerja. Jika diasumsikan teknologi padi salibu diterapkan seluas 1 juta ha dari 14 juta ha luas tanam padi di Indonesia dengan asumsi Indeks Pertanaman 200 per tahun (tanam pindah), maka akan dapat menghemat penggunaan benih sebesar 25.000 ton benih dengan harga benih Rp 8000/kg diperoleh efisiensi senilai Rp $200 \mathrm{M}$. Sedangkan keuntungan lain dari pendapatan produksi dua kali panen salibu setahun adalah $\mathrm{Rp} 28.520 .000 /$ ha/tahun atau 28,52 T/tahun (Kementan, 2015).

Kemampuan tanaman padi menghasilkan ratun dipengaruhi banyak faktor, antara lain tinggi pemotongan singgang yang berhubungan dengan asimilat hasil fotosintesis pada batang yang dapat dimanfaatkan untuk pertumbuhan tunas ratun. Tinggi pemotongan singgang juga berhubungan dengan ruas tanaman yang tersisa, dimana pada setiap bukunya akan menghasilkan tunas-tunas ratun, sehingga menentukan jumlah tunas dan anakan 
yang tumbuh yang akan berpengaruh pada jumlah malai dan jumlah gabah per malai sehingga akan mempengaruhi hasil (Noor, 2006; Harrel et al., 2009).

Secara morfologi, ratun padi tumbuh dari semua buku yang ada pada rumpun, namun ditemukan juga tunas yang keluar dari buku yang tinggi atau yang rendah saja. Ratun yang muncul dari buku lebih tinggi, menghasilkan batang yang kecil sehingga mudah patah. Adapun ratun yang muncul dari buku lebih rendah, terlihat seperti kecambah dengan daun yang kecil dan lemah. Ratun tersebut sering ditemukan membusuk karena terlalu dekat dengan air yang masih menggenangi (Mahadevappa dan Yogeesha, 1988; Nakano et al., 2009). Ratun yang muncul dari buku ketiga memiliki pertumbuhan dan hasil yang lebih baik dibandingkan ratun yang muncul dari buku yang lebih tinggi (Nakano et al., 2009).

Makarim dan Suhartatik (2006), Ai-zhong et al. (2007), Islam et al. (2008), Wijaya dan Soehendi (2012), berpendapat bahwa kemampuan tanaman menghasilkan gabah isi ditentukan oleh asimilat yang dihasilkan proses fotosintesis selama fase vegetatif sebelum memasuki fase reproduktif. Produksi ratun yang rendah dibanding tanaman utama karena ratun mengalami fase vegetatif dan generatif yang tidak seimbang. Fase vegetatif yang singkat sebelum masuk ke fase reproduktif mengakibatkan pertumbuhan dan perkembangan ratun tidak sempurna yang tercermin dari berkurangnya jumlah dan luas daun sebagai bagian yang melaksanakan proses fotosintesis, sehingga kemampuan tanaman menghasilkan asimilat menjadi terbatas yang menyebabkan rendahnya jumlah gabah dan tingginya persentase gabah hampa yang dihasilkan ratun yang akan berpengaruh terhadap rendahnya produksi.

\section{Kesimpulan}

Budidaya padi ratun dianggap lebih efisien namun jika digunakan untuk adaptasi dan mitigasi perubahan iklim secara global mungkin masih kurang karena konteksnya yang terlalu jauh. Budidaya padi ratun dapat digunakan sebagai tindakan mitigasi pada ruang lingkup yang lebih kecil. Budidaya padi ratun dapat dimanfaatkan untuk mengantisipasi dampak perubahan iklim seperti ketersediaan air yang makin terbatas jika 3 faktor di atas terpenuhi.

\section{Daftar Pustaka}

BPS. 2019. Gondangrejo Dalam Angka. BPS, Karanganyar.

Erdiman. 2012. Teknologi Salibu Meningkatkan Produktivitas Lahan dan Pendapatan Petani (Balai Pengkajian Teknologi Pertanian Sumatera Barat). Padang.

Erdiman, Nieldanina, \& Misran. 2013. Inovasi Teknologi Salibu Meningkatkan Produktivitas Lahan, Mendukung Swasembada Pangan Berkelanjutan. Balai Pengkajian Teknologi Pertanian Sumatera Barat. Padang.

Faruq G, Taha RM, Prodhan ZH. 2014. Rice Ratoon Crop: A Sustainable Rice Production System For Tropical Hill Agriculture. Sustainability, Vol. 6, No. 9, p. 5785-5800.

Kementan. 2015. Panduan Teknologi Budidaya Padi Salibu. BPTP Kementerian Pertanian, Jakarta.

Pasaribu PO. 2016. Tesis : Sifat Fisiologi dan Agronomi Padi Ratun dengan Sistem Salibu Pada Budidaya System Of Rice Intensification (SRI). IPB. Bogor.

Susilawati, dan Purwoko BS. 2012. Pengujian Varietas dan Dosis Pupuk untuk Meningkatkan Pertumbuhan dan Hasil Ratun-Padi di Sawah Pasang Surut. Jurnal Pengkajian dan Pengembangan Teknologi Pertanian. Vol. 15, no.1, Hlm: 47-54.

Wahyuni S, Zulvera, Tanjung H B, Arif E. 2019. Hubungan Karakteristik Inovasi dan Kearifan Lokal terhadap Keberlanjutan Penerapan Teknologi Padi Salibu di Kabupaten Tanah Datar, Sumatera Barat. J. Penyuluhan, Vol. 15, No. 1 Hlm: 134-143.

Nainggolan, K., I. M. Harahap dan Erdiman. 2013. Teknologi Melipatgandakan Produksi Padi Nasional. Grasindo, Jakarta.

Nakano, H., I. Hattori, K. Sato, S. Morita. 2009. Effects of double harvesting on estimated total digestible nutrient yield of forage rice. Field Crops Res. 114: 386-395. 
Harrel, D.L., A.B. Jason, B. Sterling. 2009. Evaluation of main-crop stubble height on ratoon rice growth and development. Field Crops Res. 114:396-403.

Noor, E.S. 2006. Pengaruh sistem ratunisasi dan pemupukan nitrogen terhadap hasil beberapa varietas padi di lahan sawah irigasi. J. Agrivigor. 5:207-222.

Makarim, A.K., E. Suhartatik. 2006. Morfologi dan Fisiologi Tanaman Padi. hal. 295-329. Dalam Padi: Inovasi Teknologi dan Ketahanan Pangan. Buku II. Balai Besar Penelitian Tanaman Padi.

Ai-zhong L., Z. Dong-sheng, T.U. Nai-mei, Z. Wenxin, L.Yang-xian. 2007. Relationship between distribution of photosynthesis production of flag leaf of main crop and yield of ratooning rice. J. Guangdong Agric. Sci. 23:27-34.

Islam, M.S., M. Hasannuzzaman, M. Rukonuzzaman. 2008. Ratoon rice response to different fertilizer doses in irrigated condition. J. Agric. Conspect. Sci. 73:197- 202.

Wijaya, A., R. Soehendi. 2012. Peningkatan Produksi Padi Rawa Pasang Surut melalui Penerapan Budidaya Ratun dan Perakitan Varietas yang Spesifik. Laporan Penelitian Pusat Unggulan Riset Pengembangan Lahan Suboptimal, Palembang. 